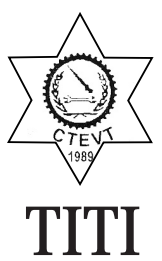

DOI: http://dx.doi.org/10.3126/jtd.v3i0.18231

ISSN: 2392-4578(Online)

\title{
Voyage from the Himalayas to the Highlands: Reflections in Technical Education
}

\author{
Anup Bhurtel \\ Management Programme, Training Department \\ Training Institute for Technical Instruction (TITI), \\ Sanothimi, Bhaktapur, Nepal \\ Email for correspondence: anupbhurtel@gmail.com; abh@titi.org.np
}

\begin{abstract}
This paper reflects on my journey from the Nepal to the United Kingdom (UK) as a student initially and then as a National Health Service (NHS) Grampian's employee. The purpose of developing this paper was to draw insights on the factors that pulled me as an urban youth for studying and living in the UK and to present the significance of skills-based technical education for the changing job market. I used analytic autoethnography to carry out this research, where I presented past epiphanies and consecutively interpreted the strong memories of those lived experiences and observations to broaden my theoretical understandings. I argued based on my lived experiences that the scope of the market based technical education is globally prevalent. For this, I have sequentially presented my stories of self-realizations and skills acquisition in the developed country such as the UK from the theoretical ideas of ethnoscapes, new and intelligent urbanism, and credentialism. Moreover, I have illuminated the relevance and significance of market based technical education courses for competing not only in Nepal but also in the global job market of the UK through self-reflection. Findings in this paper suggest the need for the international students to be pre-equipped with market based skills and to opt for market oriented subjects preferably from the field of technical education.
\end{abstract}

Keywords: Ethnoscapes, credentialism, urbanism, technical education, United Kindom (UK)

\section{Background}

Ever visited International airport to see off someone flying abroad for further education? Or heard of someone who got student Visa for higher studies? I believe we all have come across this situation and seen a young student with red $t i k a^{l}$ on the forehead and flower garlands round the neck is waving good bye with a heavy heart to their loved ones. As much as we have wished them with fortune for their bright future, we might have as well wondered what actually inspired or prompted them to go abroad and if they are well prepared for the long series of struggle or

1 A paste of rice grains and coloured power mixed with water, mostly red in colour which is used in Hindu religion in religious ceremonies and auspicious

occasions as a mark of blessing 
not. For different reasons, going abroad for education has become a youth culture in the urban society of Nepal of which I was also a character. In this paper, I present on my own journey from Kathmandu, Nepal to Aberdeen, North-East Scotland during the course of higher studies and professional work experiences. I have symbolized Nepal as the Himalayas and Scotland as the Highlands.

More specifically, I reflect on my experiences throughout my stay in London and then in Aberdeen based on which I thematically present what provoked me as an urban youth to go abroad for studies. I exhibit these findings being based on theoretical grounds. On the other hand, I present the wider scope of career in technical education across the United Kingdom (UK) which I learned from the struggles of my own and those of my fellow beings from my observations. I have used pseudonym of those I interacted with during my stay to protect their identities.

\section{Autoethnography: My Research Method}

To develop this paper, I used autoethnography under qualitative strategy as my research methodology to gain cultural understanding of self and others. Autoethnography allows the researcher to illustrate one's experiences in a well personalized style (Wall, 2006). Further Ellis, Adams \& Bochner (2011) illumine this method as both process and product in which a researcher uses doctrines of autobiography and ethnography. Hence, it facilitated me to explore the multi-hued account of the lived experiences of the self and make a deeper understanding of the social phenomenon during my stay in the UK. Rather than the style of academic report, I presented this paper in the style of research based story plots with auto/ethnographic narrative as one of the other ways of writing style of autoethnography as elucidated by Ellis and Bochner (2000) and Tillman (2009). They were based on the strong memories (and the feelings of the memories) of the characters I met and issues and tensions I experienced during my stay. Chang (2016) explains that this method utilizes ethnographic research methods to establish an association between the researcher and the society. Blending with these literatures, I presented my findings based on relevant past epiphanies illuminating the conscious interpretation of my experiences and thoughts (generated as the result of those experiences) so as to establish the connections between the personal to the social construct. Here, I have presented the plots in series of stages in reference to the work of Belbase, Luitel \& Taylor (2008).

In contrast to evocative autoethnography which Denzin (1997) explains as the research in which the researcher merely appeals to epistemology of emotions to make the reader feel emotions of the researcher and avoids emblematic issues (as cited in Anderson, 2006), I used analytic autoethnography on the ground of subjective experiences to develop a theoretical understanding. Anderson presents analytic autoethnography as a broader perspective that highlights evocative autoethnography as its subgenre. He also elaborates analytic autoethnography as such research which is inclined towards generating theoretical insight of the social phenomena through analytic reflexivity where the researcher is fully the part of the research setting, and appears as centre of the study. In the paper, I presented self as a youth from Kathmandu representing an urban society who flew to London for higher education. I maintained my own self experience in the centre of discussion. Hence, I conducted this research as an opportunistic complete member researcher keeping self in the centre and as the ultimate participant in the dual participantobserver role.

In my research, I have incorporated expressive skills and narrative fidelity along with the subjective meanings generated through dialogues with others and observations referring to Aksan, Kisac, Aydin and Demirbuken (2009). These meanings also served as my data in this paper. Anderson (2006) explains dialogue with informants beyond the self and analytic reflexivity as the components of analytic autoethnography. I met several urban youths in London and in Aberdeen whom I observed and 
interacted with. Through reflexive analysis, I presented the autoethnographic accounts of my stories from my personal experiences and these interactions looking for patterns for narratives maintaining ethnographical orientations in line to the literature of Chang (2006).

Researchers ought to focus on thick description of the phenomenon and assess findings of previous studies (Shenton, 2004). Thus in this paper, I have paid attention to details while presenting the story plots and referred to styles and patterns of published autoethnographic papers to ensure the credibility of this qualitative approach based research. In addition, I visited the sequences of utterances to reconstruct them, to consolidate textual coherence and clarity in the meaning, and to contribute to elaboration and extension of theoretical understanding.

\section{Stage One: The Transit Talk - What Pulls us There?}

It was 15 January, 2010 when I first flew in an international flight. My ultimate destination was London. The transit was in Doha where I encountered Pramod, a fellow Nepali student. During the course of conversation, I shared with him that I was going to London to pursue Master's Degree in International Business from the University of Greenwich. He then told me that he was enrolled in a cheap-private college. It had a catchy name but no strong academic ranking. He said he knew someone in a Nepali dohori $^{2}$ restaurant situated in South East London and would be working there as a waiter and earning right away. My primary intention to go to the UK was to acquire globally valued education while his was something else, I perceived.

In transit, I realized that many of the students travel abroad for various reasons, not only education. The notion of ethnoscapes as one of the global landscapes of global connectivity articulates landscapes of social beings comprising of the world we live in (Appadurai, 1990). It occurred to me that the universities from the developed countries offering courses to foreign students and the liberal immigration policies for international students have eased their movements. It has thus surged the ethnoscapes. In this connection, Nasser (2003) explains that in the UK, along with post-colonization, globalization has formed new cultural societies by South Asians and this has brought changes to its urban landscapes through every day and social processes as matter of representation. The movement of people across culture and borders has become a widespread trend with the ease in ethnoscapes (Cox, 2008; Powell \& Steel, 2011), and it blended with my own experience and observations.

In Heathrow airport's immigration section, my passport was stamped with arrival date after a few general questions about the objectives of coming to the UK. To my surprise, as I was leaving the section for luggage collection, I noticed Pramod was having difficulty to even speak properly and was being interrogated with suspicion. I joined the exodus in the arrival section with my luggage hoping that he would get clearance from that officer. I never heard from him after that.

As much as the societal phenomenon of studying abroad has become common, urban youths like me lack preparation, I think. I now realize that even I landed in London without any market oriented technical skills or trainings that could have helped me find a job earlier than I did. In every city I visited, I noticed food outlets and local bars or pubs at every other corner. A realization I thus made was that vocational trainings in related courses or technical education courses such as hotel management would generate employment focused skills and it be much helpful to get a job for students willing to work part time. Not just Pramod who was going to start working in a restaurant, but any student like me could benefit from pre-acquired related skill. Hanushek (2008) advocates for vocational education for providing specific job related skills to prepare for employment. Besides, the countries in South Asia including Nepal, due to unemployment problems, depend on foreign employments for sustainability; thus technical

2 A two way system of traditional singing practice in various regions of Nepal between male and female where completion of one instantly composed contextual paragraph by one group of sex is to be carried out spontaneously by another group of sex harmonizing with earlier lyrics 
education can foster skill development and prepare for job market for such immigrants (MartinezFernandez \& Choi, 2012). While studying in London, I as well found higher job opportunities for part time students who are skilled or have relevant trainings or education prior to job applications. My experiences thus instilled the necessity of having certain set of market oriented skills through technical and vocational education while flying abroad.

\section{Stage Two: New and Intelligent Urbanism as a Driving Factor}

In June 2010 during the semester break, I met Niglesh - a friend from the University, in Cutty Sark Greenwich. We went to McDonald's food outlet nearby for lunch and gossips. Born and brought up in the Gujarat state of India, he shared somewhat similar religious and cultural values to mine. We sat there with our meal and started casual conversations. Taking bites of chicken burger and sips of chilled Coca-Cola, I shared with him my feelings about how I was attracted to the facilities and London's public service and that I was glad to pay taxes and National Insurance for such state services. Though I did not know about the social structure of his place, he agreed that he too was impressed with council services.

I internalize how I was inclined to this culturalsocial-economic phenomenon termed as urbanism as an urban youth. I was fascinated by systematic and accountable councils, basic facilities for living, social security and such. The global prevalence of urbanism had long been identified, and studied (Wirth, 1938) which still prevails in urban societies of Nepal and even in my neighbouring country. Moreover, new urbanism is applied to address the diversity in the urban social settings and acknowledge participation of new urbanists (Day, 2003). I believe that the quality of life with respect to facilities in community was the reason why I was fascinated to live in the UK.

After completing my study, I moved to Aberdeen in January 2012. I had to again register for the General
Practitioner (GP) there at nearby locality. It is the clinical service for basic health check-ups and referent point to the hospitals. It functions under National Health Service (NHS). I did not need much medical attention during my tenure as a student but I needed one when I moved to Aberdeen. In February 2013 month, I was referred to a hospital by the GP to check up on issues I had been having in my ear drum. Upon inspection by an Indian doctor - an Ear Nose Throat (ENT) specialist, I was informed that I needed a surgery which was scheduled one month later. It was a bit worrisome for me as I had no family there and my own well being was the key to my survival. But their services gave me confidence that I was in good hands. My surgery was successful and I received individualized care during the whole time. I was given paid leave from my employer for nearly three weeks which was abundant for full recovery in my case. I had never been that impressed in my life with such quality and free health services (including medicines) which I received in Scotland.

I connect this experience to new urbanism which functions in line with smart growth policy and acknowledges place diversity (Grant \& Perrot, 2009; Trudeau \& Kaplan, 2015). To me, there is no better example of smart growth policy and acknowledgement of diversity than of NHS which treats people's health first, provides equal health services irrespective of immigration status. From both the hospital and my employer, I received the facilities which were no different than what a British citizen would receive. It still amazes me and I now reflect it to intelligent urbanism. It is also about processes along with architects that incorporates a vision of tolerant and equitable societies (Benninger, 2002). Thus, I also link my experience of my worklife in this connection. My employers always acknowledged my identity as a Nepalese and respected the diversity in the workplace. They gave priority to work rather than ethnic backgrounds. This respectful behaviour both at the office and the society which was not different from a native British serves as another example of intelligent urbanism. I now understand and infer that this new and intelligent 
urbanism existing in practice in the western society provokes youths like me to settle there in long run.

\section{Stage Three: Essential Credential}

My decision to pursue master's degree from a university in the UK was guided by increasing demand for competencies and educational qualifications, and the credential values of UK's universities. Brown (2001) explains the theory of credentialism as the social phenomenon that involves reliance on formal credentials or increased demand for formal qualification of education that has been devaluing the qualifications. The social construct of our urban societies are such that we value the individuals who measure the intelligence and ability of the individuals based on their formal qualifications and value those who have such higher level of formal education. I was raised in the family and neighbourhood where we were compared with our contemporaries based on our educational performances. As a result, I possessed this culturally and socially acquired way of thinking from my childhood that reflects to Bourdieu's notion of habitus (Morrison, 2006; James, Busher \& Suttill, 2016). This embedded mental disposition led me to determine pursuing master's degree from a renowned university, preferably from a developed country.

During the course of stay in Aberdeen, I met a few Nepalese fellow beings from Nepal pursuing their second master's degree. They were hopeful they would find better job back in Nepal which their first credential of master's degree from Nepal was unable to get. I reflected that the web of the effect of credentialism for Nepalese was widespread across the UK since it reminded me of my struggles after graduation in Bachelor's degree in Business Administration when I began searching for job. It took me a couple of months before I found one while my friends were still searching. I analyze that the limited job market filled up with stiff competition signifies employers' preference to human capital with higher credentials.

Human capital theory posits that schooling is the responses to the increased demand of skilled workforce (Becker, 1964 as cited in Walters, 2004). In line to this, Walters explained the human capital theory also has found that the credentials correspond with the needs of the employers. Immigrants with undervalued credentials from their home countries carry deficit in human capital (Li, 2008). I internalize that I myself was highly influenced by the value of higher degree from abroad. Hence, going to London was the result of my decision to strengthen my academic qualifications. As Li suggested, foreign credentials benefit majority of immigrants. In my case, I wanted to stand out of the crowd, be it in the UK, or in Nepal, which I eventually gained across time. Later I found that this was also the desire of my friends.

On a mild sunny day in the early summer of 2014, I and my friends were sitting in a park, on a green moist ground watching some native teenagers play football. We were enjoying our day off when Laxman shared his feelings out of nowhere, "I cannot wait to complete my study and start a decent job in Kathmandu. I am the youngest of all. If I complete this course, my family and cousins will value me more." With this, Rabin added that he used to feel worthless especially he was being compared in studies with other youths in his society and relatives by his own family. But with a breath of pride, he continued that later he occasionally remitted money and both his family and society treated him with respect for his education in the UK. My story was also a part of this. I too shared with them that soon after I completed my degree and started doing a decent job in NHS Grampian, the way my society perceived me drastically changed. I also shared with them a funny fact that many people approached me with the proposal of arranged marriage for their nephews or cousins and such. This seeded laughter and we continued talking other stuff related to our current life of that time.

I now analyze how credentialism has also been linked with social stratification. The same society that treated me and my friends as an ordinary youth, now 
distinguishes us as valuable members of the society. In this connection, Morrison (2006) explains Max Weber's theory social class and status group as the conflict theories by articulating the conflict that arise from the class interests and status groups. I further relate this to Collin (1979) who states that there exist a strong relationship between credentialism and stratification of the class (as cited in Armstrong, 1981). I have observed that credential attainments create distinct class divisions in our urban societies. Thus, for youths like me, owning a foreign degree was the key to better earning and strata upliftment. In fact, "The content and occupational significance of credentials are more cultural and exclusionary" (Brown, 2001, p. 20). My own image in my society strengthened after I completed MBA which helped me have a good job, and subsequently emerge as a role-model for my cousins or neighbours in the society. On the other hand, due to educational inflation, the youths are bound to have higher degree than their parents to achieve social class (Van de Werfhorst \& Andersen, 2005). In my context, my father had his second master's degree from the UK due to which I too felt the obligation of living up to that standard and establishing my image as a learned person in the society. In this way, the expectation of getting better job opportunities either in home country or abroad and raising one's strata in friend's circle or society as a whole has as well lured me as an urban youth to study abroad.

\section{Meta Stage: Technical Education and Career Scope}

Urban youth culture of studying abroad has been strongly influenced by the deeply rooted issues of credentialism in our society and the job market which has been facilitated by ethnoscapes and further triggered by new and intelligent urbanism. Reflecting on my overall experiences during my stay in the UK, here I associate with how technical education has been linked with all the three stages and it begins with my career choice.

The career choices we make are guided by our interests, family and social influence, the market demands and other factors. The choices depend on the availability of career options and individual preferences. Moreover, personality and demographic variables influence on career choice behaviours (Özbilgin, Küskü, \& Erdogmus, 2005). Agarwala (2008) further argues personal and cultural values as well as structural factors are the determinants of career choices. In my case, the decision to study 24 months - Master's degree in business Administration (MBA) in International Business was based on my personal interest and the structural factors. Enchanted by the glowing and growing charm of MBA in the urban places in Nepal, I was convinced that I would be saleable either in the UK or Nepal. Besides, I was under the impression that a UK's university degree in any stream in management or business would be fruitful for the career. However, the experiences I had while searching for jobs were on the contrary. Though there were numerous vacancies from different employers including multinational companies, there were mostly clauses of immigration and besides, the competition was unimaginable due oversupply of graduates of such general subjects. For fresh graduates with merely a couple of years' experiences like me, it was next to miracle to stand out among hundreds of competitors from the UK, Europe and beyond. This made me understand the necessity to have highly market focused degree, preferably of technical fields.

A few months after working in Admin Support Department in National Health Service (NHS) Grampian which I commenced in the summer of 2012, I offered myself to work in Payroll department within Human Resource Service Centre to cover its workload. I worked as a resource person for few months. With this experience, I was selected for the post of Trainee payroll officer when there was a vacancy announcement for the same post in November 2013. My career advanced after I started this technical job with regular informal trainings. I received frequent trainings during the job by the senior payroll officers or supervisors which usually were based on cognitive apprenticeship model. Dennen (2004) explains cognitive apprenticeship as 
social learning method in which experts assist the novices to equip them with necessary job related cognitive skills. In my job, I along with the two new recruited officers was trained to develop cognitive skills rather than physical psychomotor skills. We were periodically trained on the e-payroll system through demonstration with guided practice followed by independent practice, and ultimately real job tasks. My career took better shape with the legitimate participations in training and gradual skills acquisition. However, it took me over a year to reach to that Band 5 level job from Band 2 that made me realize that technical education had more scope than general education in my case.

The realization further consolidated after meeting quite a few Nepalese friends and neighbours during my stay in Aberdeen from 2012 to mid 2014. I observed that they were still struggling to find a job related to their field even after graduating their courses. Apparently, many of them had graduated in the subject of general education field based on their own interests rather than those of market demands. In contrast, a few I met who had graduated in technical subjects and were enjoying their highly paid jobs. In October 2013, I and my flat-mate Sujan were invited by Sujan's cousin sister to celebrate Dashain $^{3}$ festival in Dundee - a small town in Scotland which was two hours drive away from Aberdeen. She was a senior nurse herself residing there as a British citizen. In the gathering she organized, I met a couple of her friends who were Information and communications technology (ICT) graduates. They were working in their respective fields with highly paid jobs and were living as permanent residents. Based on the interactions with all of them, I found that employers value competent employees with skills rather than ethnical backgrounds. Now I reflect those experiences as I advocate the necessity of opting for technical education to acquire specific skills in order to compete in the job market as the fresh graduates. personal interest without realizing market demand of foreign soil was prevalent in my experience. While searching for online jobs, I came across thousands of vacancies but most of them demanding technical expertise and experiences. I found more vacancies in the field of technical education than general education and that the demands were high and frequent with attractive pay scales comparatively. As explained by Beyon, Kellen and Kishor (1998), the career choices that are broadly classified into intrinsic (personal interest, satisfaction); interpersonal (influence of family or companions); and external (market demands, pay scale, availability of jobs). External factors did matter more in my experience since I also had to struggle for a few months to find a decent job after the completion of my study. The market worth of credentials of immigrants is unclear and their credentials carry a penalty compared to the natives ( $\mathrm{Li}, 2001)$. As many jobs had immigration related clauses, it was more difficult for me to match the eligibility criteria. A lesson I learned is that when we have options around, it is more sensible and wiser to select the courses that have high demand in either the market of UK or Nepal considering external factors.

External factors hold more significance to those who are oriented to protean career. Hall (2004) explains it as the self-directed career which is proactively managed by individuals and is value driven. As my career orientation was protean rather than conventional, I learned that one should consider all the scopes of job market, acknowledge work uncertainty and have preparedness with professional passion. I reflect on how the scope of technical education in Nepal is gradually rising. Technical education as well as vocational training are not just associated with job market positively, but also help strongly in reducing unemployment (Tan \& Chandrasiri, 2004). As it is said 'better late than never', I realize the bright scope of technical education in the UK, and not just in Nepal from my own personal experiences.

The blunder of selecting courses just based on

3 One of the biggest festivals of Hindu people in Nepal celebrated for 10 days in which goddess Durga Bhawani is worshipped and usually falls in October in Gregorian calendar 


\section{Wrapping up the Discussion}

I had a series of stressful but fruitful experiences during and after the study which were no less than a ride in a roller-coaster. In this paper, I have selfreflected the series of my memories and feelings associated with them from past from the current perspectives and applicable theoretical lenses. I thus expanded the theoretical understanding on the ground of self-realizations. I explored links among ethnoscapes, credentialism, new and intelligent urbanism and skills based technical education with respect to international job market.

My personal experiences helped me comprehend that the ethnoscape has become a common phenomenon for international students like me. In this regard, I was influenced by credentialism that is the value my society has put to the attainment of higher formal education that pushed me to go to the UK and acquire master's degree to uplift my position in society and strengthen my career. Thus, the global movements of students like me from urban places of Nepal have been provoked by credentialism and facilitated by the trend of ethnoscapes. Further, an interesting exploration I made was pertinence of the new and intelligent urbanism as another persuading factor for youths like me who choose to study abroad, and moreover, to settle there in the long run. I was deeply impressed with public services, respect for diversity in workplace and the community and moreover, value for competencies or skills. I noted the relevance of market based jobs mostly offered by technical educations in order to sustain and succeed over there.

My lived experiences and observations made me internalize how important it is to choose the subjects under technical education which are market based. Through analytic autoethnography, I presented the emblematic issues to illuminate the gap between 'what should be' and 'what is' with respect to my realization on the significance of technical education. I explicate that though the movement of credentialism-driven international students like me have been simplified opening the gateways for long term settlements, it is essential to choose market based courses which are basically technical subjects. This is imperative to be successful either in developing country such as Nepal, or advanced economy like the UK. Through autoethnography, I was able to methodologically analyze my lived experiences of studying and living abroad from different theoretical lenses and advocate the scope of technical education throughout the world.

\section{References}

Agarwala, T. (2008). Factors influencing career choice of management students in India. Career Development International, 13(4), 362-376. doi: 10.1108/13620430810880844

Aksan, N., Kisac, B., Aydin, M., \& Demirbuken, S. (2009). Symbolic interaction theory. Procedia Social and Behavioral Sciences, 1(1), 902-904. doi: 10.1016/j.sbspro.2009.01.160

Anderson, L. (2006). Analytic autoethnography. Journal of Contemporary Ethnography, 35(4), 373-395. doi: 10.1177/0891241605280449

Appadurai, A. (1990). Disjuncture and difference in the global culture economy. Theory, Culture, and Society. 7(1), 295-310. doi:10.1177/026327690 007002017

Armstrong, C. F. (1981). The credential society: An historical sociology of education and stratification. By Randall Collins. Social Forces, 59(3), 861 863. Retrieved from http://www.jstor.org/ stable/2578213

Benninger, C. C. (2002). Principles of intelligent urbanism: The case of the new capital plan for Bhutan. Ekistics, 69(412/413/414), 60-80. Retrieved from http://www.jstor.org /stable/4 3619538

Belbase, S., Luitel, B. C., \& Taylor, P. C. (2013). Autoethnography: A method of research and teaching for transformative education. Journal 
of Education and Research, 1, 86-95. doi: 10.3126/jer.v1i0.7955

Beyon, J., Kelleen, T. and Kishor, N. (1998). Do visible minority students of Chinese and south Asian ancestry want teaching as a career? Perceptions of some secondary school students in Vancouver, BC. Canadian Ethnic Studies, Vol. 30(2), 50-73. doi: 10.1108/13620430810880844

Brown, D. K. (2001). The social sources of educational credentialism: Status cultures, labor markets, and organizations. Sociology of Education, 74(1), 19-34. Retrieved from http://www.units.miamioh.edu/eduleadership/ faculty/quantz/Courses/credentialism.pdf

Chang, H. (2016). Autoethnography as method. Routledge.

Cox, M. (2008). Globalisation: Are you for or against it ? Teaching Geography, 33(2). 75-76. Retrieved from http://www.jstor.org/stable/23755294

Day, K. (2003). New urbanism and the challenges of designing for diversity. Journal of Planning Education and Research, 23(1), 83-95. doi: 10.1177/0739456X03255424

Dennen, V. P., \& Burner, K. J. (2008). The cognitive apprenticeship model in educational practice. In M. D. Merrill , J. Merrienboer , M. J. Spector , M. P. Driscoll , D. Jonassen, \& M. Driscoll (Eds.), Handbook of research on educational communications and technology, 3(1), 425-439. doi: 10.4324/9780203880869

Ellis, C., Adams, T. E., \& Bochner, A. P. (2011). Autoethnography: An overview. Historical Social Research/Historische Sozialforschung, 12(1), 273-290. Retrieved from: http://www.jstor.org /stable/23032294

Ellis, C., \& A. P. Bochner. (2000). Autoethnography, personal narrative, reflexivity: Researcher as subject. In N. K. Denzin \& Y. S. Lincoln (Eds), Handbook of qualitative research, (Vol. 2, pp. 733-768). Thousand Oaks, CA: Sage Publications.

Grant, J., \& Perrott, K. (2009). Producing diversity in a new urbanism community: Policy and practice. Town Planning Review, 80(3), 267-289. Retrieved from http://www.jstor.org/stable/2 7715103

Hall, D. T. (2004). The protean career: A quarter century journey. Journal of Vocational Behaviour, 65(1), 1-13. doi: 0.1016/j.jvb.2003.10.006

Hanushek, E. A. (2013). Economic growth in developing countries: The role of human capital. Economics of Education Review, 37(1), 204-212. doi: 10.1016/j.econedurev.2013.04.005

James, N., Busher, H., \& Suttill, B. (2016). Using habitus and field to explore Access to Higher Education students' learning identities. Studies in the Education of Adults, 47(1), 4-20. doi: 10.1080/02660830.2015.11661671

Li, P. S. (2001). The market worth of immigrants' educational credentials. Canadian Public Policy, 27(1), 23-38. Retrieved from http://www.jstor.org/stable/3552371

Li, P. S. (2008). The role of foreign credentials and ethnic ties in immigrants' economic performance. The Canadian Journal of Sociology, 33(2), 291 310. Retrieved from http://www.jstor.org /stable/canajsocicahican.33.2.291

Martinez-Fernandez, C., \& Choi, K. (2012). Skills Development Pathways in Asia. In R. Maclean, S. Jagannathan, \& J. Sarvi (Eds.), Skill development for inclusive and sustainable growth in developing Asia-Pacific, (Vol. 19, pp. 155 179). New York, NY: Springer.

Morrison, K. (2006). Marx, Durkheim, Weber: 
Formations of modern social thought (2nd ed.). New Delhi: Sage Publications India.

Nasser, N. (2003). South Asian Ethnoscapes: the changing cultural landscapes of British cities. Global Built Environment Review, 3(2), 26-39. Retrieved from http://www.globalbuilt environment review.co.uk/Documents 13.2\%20Article\%202.pdf

Özbilgin, M., Küskü, F., \& Erdogmus, N. (2005). Explaining influences on career 'choice': The case of MBA students in comparative perspective. The International Journal of Human Resource Management, 16(11), 2000-2028. doi: 10.1080/09585190500314797

Powell, J. L. \& Steel. R. (2011). Revisiting Appadurai: Globalizing scapes in a global world - The pervasiveness of economic and cultural power. International Journal of Innovative Interdisciplinary Research, 1(1), 74-80. Retrieved from http://www.auamii.com/jiir/Vol-01/issue 01/X9.Power.pdf

Shenton, A. K. (2004). Strategies for ensuring trustworthiness in qualitative research projects. Education for information, 22(2), 63-75. Retrieved from: https://pdfs.semanticscholar.org /452e/3393e3ecc34f913e8c49d8faf19b9f89b 75d.pdf

Tan, H., \& Chandrasiri, S. (2004). Training and labor market Outcomes in Sri Lanka. World Bank Institute Working Paper, Washington, DC. Retrieved from: http://info.worldbank.org/etools /docs/library/235725/Training\%20and\%20Labor \%20Market\%20Outcomes\%20in\%20Sri\%20 Lanka.pdf

Tillman, L. M. (2009). Speaking into silences: Autoethnography, communication, and applied research. Journal of Applied Communication Research, 37, 94-97. doi: 10.1080/0090 9880802592649
Trudeau, D., \& Kaplan, J. (2016). Is there diversity in the New Urbanism? Analyzing the demographic characteristics of new urbanist neighborhoods in the United States. Urban Geography, 37(3), 458-482. doi: 10.1080/027236 38.2015.1069029

Van de Werfhorst, H. G., \& Andersen, R. (2005). Social background, credential inflation and educational strategies. Acta Sociologica, 48(4), 321-340. Retrieved from http://www.jstor.org/ stable/20059962

Wall, S. (2008). Easier said than done: Writing an autoethnography. International Journal of Qualitative Methods, 7(1), 38-53. doi: $10.1177 / 160940690800700103$

Walters, D. (2004). The relationship between postsecondary education and skill: Comparing credentialism with human capital theory. Canadian Journal of Higher Education, 34(2), 97-124. Retrieved from http://journals.sfu.ca /cjhe/index.php/ cjhe/article/view/183458

Wirth, L. (1938). Urbanism as a way of life. American journal of sociology, 44(1), 1-24. Retrieved from http://links.jstor.org/sici?sici $=0002$ $9602 \% 28193807 \% 2944 \% 3$ A $1 \% 3 \mathrm{C} 1 \% 3$ AUAAWOL\%3E2.0.CO\%3B2-B 